\title{
Influence of Meat Spoilage Microbiota Initial Load on the Growth and Survival of Three Pathogens on a Naturally Fermented Sausage
}

\author{
Luis Patarata ${ }^{1,2, *(D)}$, Margarida Novais ${ }^{2}$, Maria João Fraqueza ${ }^{3}\left(\mathbb{D}\right.$ and José António Silva ${ }^{1,2}$ \\ 1 CECAV, Centro de Ciência Animal e Veterinária, 5001-801 Vila Real, Portugal; jasilva@utad.pt \\ 2 School of Agrarian and Veterinary Sciences, Universidade de Trás-os-Montes e Alto Douro, \\ 5001-801 Vila Real, Portugal; luiscpatarata@gmail.com \\ 3 CIISA, Centro de Investigação Interdisciplinar em Sanidade Animal, Faculdade de Medicina Veterinária, \\ Universidade de Lisboa, Avenida da Universidade Técnica, 1300-477 Lisboa, Portugal; \\ mjoaofraqueza@fmv.ulisboa.pt \\ * Correspondence: lpatarat@utad.pt; Tel.: +351-259350539
}

Received: 6 May 2020; Accepted: 21 May 2020; Published: 25 May 2020

\begin{abstract}
Meat products are potential vehicles for transmitting foodborne pathogens like Salmonella, $S$. aureus, and L. monocytogenes. We aimed to evaluate (1) the effect of the meat's initial natural microbiota on Salmonella, S. aureus, and L. monocytogenes growth and survival in a batter to prepare a naturally fermented sausage, made with and without curing salts and wine (2) the effect of a lactic acid bacteria (LAB) starter culture and wine on the survival of the three pathogens during the manufacturing of a naturally fermented sausage made with meat with a low initial microbial load. The results revealed that the reduced contamination that is currently expected in raw meat is favorable for the multiplication of pathogens due to reduced competition. The inhibitory effect of nitrite and nitrate on Salmonella, S. aureus, and L. monocytogenes was confirmed, particularly when competition in meat was low. In any attempt to reduce or eliminate nitrite from naturally fermented sausages, the use of $\mathrm{LAB}$ starters should be considered to ensure an unfavorable competition environment for pathogens. In the experiment with naturally fermented sausage, chouriço, the reduction in $\mathrm{a}_{\mathrm{w}}$ strongly inhibited the challenged pathogens, particularly when a LAB starter culture and wine were used.
\end{abstract}

Keywords: naturally fermented sausage; spoilage microbiota; starter culture; lactic acid bacteria; wine; nitrite; foodborne pathogens; Salmonella; Staphylococcus aureus; Listeria monocytogenes

\section{Introduction}

European and North American foodborne surveillance data point out meat and meat products as food vehicles that are frequently associated with foodborne disease outbreaks [1,2]. Salmonella is one of the pathogens most frequently found in outbreaks resulting from fermented sausage consumption. Due to the severity of the disease, widespread distribution in processing plants, and to the theoretical adequacy of the fermented sausage ecosystem to support its growth, Listeria monocytogenes must be considered as a potential hazard in the manufacturing of these products. Staphylococcus aureus can grow in foods with a reduced water activity $\left(\mathrm{a}_{\mathrm{w}}\right)$. Thus, it should be prevented when preparing fermented sausages [3-5].

The preventive hygienic measures implemented at slaughterhouses aim to achieve a low initial contamination and control the safety of meat. However, any pathogen presence during processing should be considered. When the initial microbial contamination on meat is low and no starter cultures are added, pathogens face less competition, increasing the odds of their fast multiplication $[6,7]$. The fermentation carried out by the natural microbiota of meat and by the so-called house microflora, 
or by the addition of starter cultures, combined with the reduction in water activity, are the main hurdles to several pathogens [8,9]. In the meat processing industry, it is common to use nitrite, alone or in combination with nitrate, to control Clostridium botulinum and due to their effect on color stabilization [10]. These chemical preservatives also have a reputed inhibitory effect on other foodborne pathogens with importance in the meat product industry, namely Salmonella, L. monocytogenes, and $S$. aureus $[11,12]$. The association between colon cancer and processed meats is mediated among other aspects by the eventual formation of N-nitroso-compounds in meat products prepared with nitrite [13]. Nowadays, the consumer demand for additive-free meat products is growing [14,15]. Potential health problems and consumer behavior have led to a trend towards eliminating or decreasing the level of nitrite in the meat industry. Nonetheless, despite the apparently favorable context to reduce or eliminate nitrite, the meat industry is still very reluctant to take this step. The fear of foodborne outbreaks and the expectation that consumers might appreciate products less due to unsatisfactory color are believed to be the main hurdles [16]. To reduce nitrite in dry sausages, it is important to understand how pathogens will be controlled to validate their safety. The safety of dry sausages relies on hurdle technology, a combination of several preservation techniques. In addition to the reduced $\mathrm{a}_{\mathrm{w}}$ and the activity of lactic acid bacteria (LAB), other aspects can exert important hurdle effects on pathogen growth or survival, namely reduced temperature during processing and low $\mathrm{pH}$, the use of preservatives, smoking, the eventual antimicrobial effect of spices and herbs, and wine [17]. In wine-producing regions, it is common to season dry sausages with wine [18-22]. Wine is claimed to have antimicrobial potential in marinated meat and meat products $[19,23]$. The antimicrobial effect of wine in dry-fermented sausage safety might be associated with its low $\mathrm{pH}$ and the presence of ethanol and phenolic compounds [24]. The survival and growth of pathogens is modulated by the ensemble of factors present in food. In the present work, we aimed to evaluate (1) the effect of the initial meat natural microbiota load on Salmonella, S. aureus, and L. monocytogenes growth and survival in a batter to prepare a naturally fermented pork sausage, made with and without curing salts and wine, and secondly, (2) the effect of a LAB starter culture and wine on the survival of the three pathogens during the manufacturing of a naturally fermented pork sausage made with meat with a low initial microbial load.

\section{Materials and Methods}

\subsection{Experimental Design}

The experiment was composed of two parts. In the first part of the study, a batter similar to that used for naturally fermented pork sausage manufacturing was used to study the effect of the initial contamination of meat, nitrite, and nitrate and wine on the behavior of Salmonella, S. aureus, and L. monocytogenes. In the second part of the study, the effects of wine and wine plus a LAB starter culture on the behavior of the three pathogens in chouriço were studied. The design of the experiment is presented in Figure 1. 
Part 1

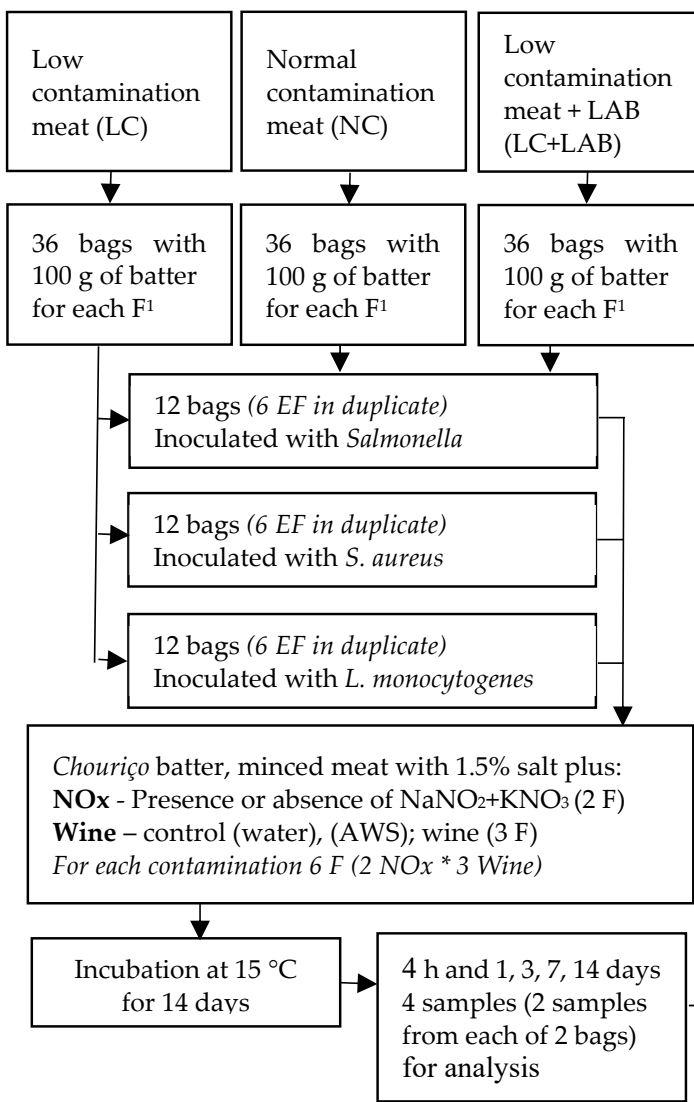

Part 2

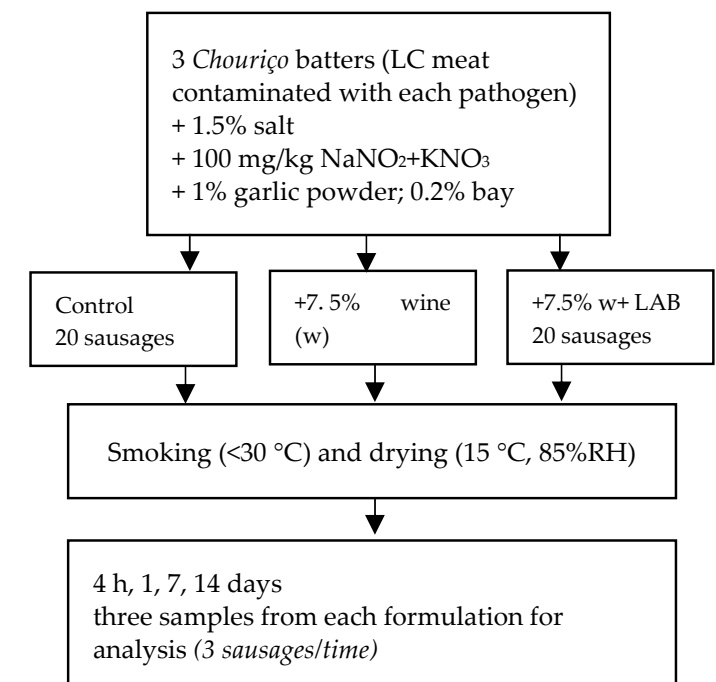

three samples from each formulation for

analysis (3 sausages/time)

Figure 1. Experimental design. ${ }^{1}$ EF Experimental Formulation.

\subsection{Bacterial Strains and Preparation of Inoculum}

For each tested pathogen, a mixture of three strains was used (Table 1), one strain from a culture collection and two wild-type strains isolated from meat products or their production environment. For inoculation, $24 \mathrm{~h}$ single cultures in $30 \mathrm{~mL}$ of Brain Heart Infusion (BHI, Biokar, Allonne, France) were harvested by centrifugation, washed twice, and suspended in $\mathrm{NaCl} 0.85 \%$. Mixtures of the three strains were prepared and diluted to achieve a level of inoculation of ca. $2.5 \mathrm{log} \mathrm{cfu} / \mathrm{g}$, as recommended for microbiological challenge testing [25,26]. Lactobacillus sakei (Lch45), which was previously tested for its antagonistic activity [27], was prepared similarly to the pathogens, but using De Man, Rogosa, and Sharpe (MRS) broth. The level of inoculation was adjusted to $6 \log \mathrm{cfu} / \mathrm{g}$.

Table 1. Strains used in the experiment.

\begin{tabular}{ccc}
\hline Salmonella & S. aureus & L. monocytogenes \\
\hline CECT 4155 & ATCC 25923 & NCTC 7973 \\
\hline MPI-B-S07 ${ }^{1}$ (Chouriço batter) & EDS-B-LM05 ${ }^{1}$ (Chouriço batter) & $\begin{array}{c}\text { EDS-ChM-SA01 }{ }^{1} \text { (Chouriço at the } \\
\text { middle of the drying process) }\end{array}$ \\
\hline $\begin{array}{c}\text { EDS-E-S26 }{ }^{1} \text { (Environment of meat } \\
\text { products preparation) }\end{array}$ & $\begin{array}{c}\text { MPI-E-LM18 }{ }^{1} \text { (Environment of } \\
\text { meat products preparation) }\end{array}$ & $\begin{array}{c}\text { EDS-E-SA07 }{ }^{1} \text { (Environment of } \\
\text { meat products preparation) }\end{array}$ \\
\hline
\end{tabular}

\footnotetext{
${ }^{1}$ Strains isolated from meat products or the environment of its production are from our laboratory collection.
}

The concentration of microorganisms was estimated by the turbidity of the suspension. It was adjusted to a $0.5 \mathrm{McF}$ arland standard (Biomerrieux, Marcy-l'Etoile, France) and adequate decimal dilutions were made in $\mathrm{NaCl} 0.85 \%$ to achieve the required inoculation level. The number of 
microorganisms in the inoculation suspension was confirmed by seeding the pathogens in $\mathrm{BHI}$ agar: Inoculum of $L$ sakei was serial diluted in $\mathrm{NaCl} 0.85 \%$ and seeded in solid MRS.

The concentration of microorganisms was estimated and confirmed as described for pathogens.

\subsection{Part 1. Experiments with a Chouriço Batter}

All experiments were prepared using meat and fat from pork belly. Pork bellies were purchased in a local retailer on the day of arriving from the abattoir. To prepare meat with low contamination (LC), pork bellies were immersed in ethanol; the surface of the meat was burned with a blowtorch, and the burned surfaces were excised under aseptic conditions. Only non-heated meat was used for further experiments. Normal contaminated meat (NC) was used as it was purchased. To assess the initial microbiota of meat, Enterobacteriaceae, Pseudomonas, and LAB were enumerated. The reductions obtained through the treatment were between 1 and $2 \log \mathrm{cfu} / \mathrm{g}$ (see Section 3.1). Then, $12 \mathrm{~kg}$ of meat and fat from the pork bellies (4 $\mathrm{kg}$ of each contamination level) were ground $(15 \mathrm{~mm}$ ) (Mainca, Barcelona, Spain) and, for each initial microbiota contamination level (LC, NC, LC + BAL), distributed into 36 polyethylene bags containing $100 \mathrm{~g}$. Twelve bags containing meat at each initial contamination level were inoculated with Salmonella strains, 12 bags were inoculated with S. aureus strains, and 12 bags were inoculated with L. monocytogenes strains. Inoculated meat was homogenized with a stomacher (3 min). For low contaminated meat with L. sakei (LC + LAB), the starter culture was added after inoculation with pathogens.

To guarantee the distribution of the tested ingredients, they were added individually to each bag. Sodium nitrite and potassium nitrate (hereafter referred to as NOx) were added to achieve a level of $150 \mathrm{mg} / \mathrm{kg}$ batter. To test the effect of wine (W), 7.5\% red wine was used (pH 3.8, 12.5\% ethanol) and a solution to imitate wine, thereafter called artificial wine solution (AWS), was prepared with ethanol $(12.5 \%)$, tartaric acid $(0.22 \%)$, lactic acid $(0.20 \%)$, malic acid $(0.12 \%)$, succinic acid $(0.12 \%)$, and acetic acid $(0.05 \%)$ [28]. Artificial wine solution was used to evaluate if the putative inhibitory effect of wine was associated with the ethanol and the combination of organic acids that are usually present in wine. Inoculated meat was seasoned with $1.5 \%$ salt. Other ingredients were added according to the experimental design. Two units of $100 \mathrm{~g}$ were prepared for each experimental condition. After removing the air, the bag was closed with a clip. The batters were incubated at $15^{\circ} \mathrm{C}$, which is a mean temperature usually used by several producers to cure/dry sausages [23]. Two samples of $5 \mathrm{~g}$ were withdrawn from each bag after $4 \mathrm{~h}$ and 1,3, 7, and 14 days and prepared for analysis.

\subsection{Part 2. Experiment with a Naturally Fermented Sausage-Chouriço}

The naturally fermented sausage was prepared as described for the batter experiment. Meat inoculated with each pathogen was distributed in three batches. All samples were seasoned with $1.5 \%$ salt, $1 \%$ dried garlic, and $0.2 \%$ powdered bay leaves. Curing salts $\left(5 \% \mathrm{NaNO}_{2}\right.$ and $\left.5 \% \mathrm{KNO}_{3}\right)$ were added at $0.20 \%$ to achieve a level of $100 \mathrm{mg} / \mathrm{kg}$ in the sausage batter. Three formulations were prepared: Control, with no further ingredients; Wine, with 7.5\% red wine; and Wine + LAB, with 7.5\% red wine and $6 \log \mathrm{cfu} / \mathrm{g}$ L. sakei. After mixing, the batter was filled into a thin natural pork casing and tied in a horseshoe shape (each sausage weighed ca. $200 \mathrm{~g}$ ). The smoking occurred in a chamber (Begarat, Thermaxs 100EC, Berlin, Germany) with an electric resistor applied to fireless burn beech wood scraps for $3 \mathrm{~h}$ at a temperature between 25 to $30^{\circ} \mathrm{C}$. The drying was done in a climatic chamber at $15^{\circ} \mathrm{C}, 85 \%$ RH (Aralab Fitoclima, Rio de Mouro, Portugal) until day 14.

Three sausages were collected for analysis at each experimental time $4 \mathrm{~h}$ after the batter's preparation, after smoking (day 1), and after 7 and 14 days of drying.

\subsection{Bacterial Enumeration}

As the inoculation levels were low (near $2 \log \mathrm{cfu} / \mathrm{g}$ ) and close to the counting methods' detection limit, an initial dilution of $1: 5$ was prepared in $0.85 \% \mathrm{NaCl}$. When low counts were expected, an inoculation of $0.5 \mathrm{~mL}$ of the first dilution was spread on two Petri dishes $(0.25 \mathrm{~mL}$ each) and slightly 
dried in the laminar flow for $5 \mathrm{~min}$ to avoid biofilm formation during incubation. When high counts were expected, appropriate serial dilutions were used and the standard $0.1 \mathrm{~mL}$ inoculation was made. Compass Salmonella, Baird Parker with Rabbit Plasma Fibrinogen (RPF), and Compass Listeria were used to enumerate the three pathogens, followed by incubation at $37^{\circ} \mathrm{C}$ for the first two methods and $30^{\circ} \mathrm{C}$ for the last method. After 24 to $48 \mathrm{~h}$ of incubation, typical colonies were enumerated. LAB were enumerated in MRS, Enterobacteriaceae in Violet Red Bile Glucose agar (VRBG), and Pseudomonas in Caphaloridine Fucidin Cetrimide agar (CFC). All culture media were from Biokar (Allonne, France). The results are expressed as $\log \mathrm{cfu} / \mathrm{g}$, obtained by the application of the following expression:

$$
\log _{10}\left[\frac{c f u}{\left[\left(\frac{m}{V+m}\right) \cdot v i \cdot\left(\frac{1}{d f}\right)\right]}\right]
$$

$m$-weight of the sample (5 g). v-volume used in the initial dilution $(20 \mathrm{~mL}) . v i-$ volume (mL) used in the petri dish ( 0.5 low counts, 0.1 normal). $d f$-dilution factor (in undiluted samples was 1 ).

For data analysis purposes, when the microorganism count was below the detection limit ( $1 \log \mathrm{cfu} / \mathrm{g}$ ), the count was considered to be zero. When countable colonies were present but below the recommended countable range, the counts were considered an estimate for data analysis purposes.

\section{6. $\mathrm{pH}$ and Activity of Water}

The $\mathrm{pH}$ was measured following homogenization of $10 \mathrm{~g}$ samples with $100 \mathrm{~mL}$ of deionized water in a lab mixer for $30 \mathrm{~s}$ (model MicropH 2002, Crison, Barcelona, Spain). Water activity was measured with a Hygroscope DT apparatus with a WA40 probe (Bassersdorf, Switzerland).

\subsection{Data Analysis}

The normality of the variable was tested using the Kolmogorof-Smirnov test. The distribution of the variable for each group defined by the effect level was non-normal. Comparisons between samples made with or without NOx was made through the Mann-Whitney test. For variables with three levels (initial contamination: LC. NC, LC + BAL; Wine: control, wine, AWS), the comparisons of the bacterial counts were made using the Kruskal-Wallis test. The differences $(p<0.05)$ between different formulations were located by the Dunn test with the Bonferroni correction (XLStat, Addinsoft). As the evolution of the pathogens is presented in graphs based on mean values, the tables presenting the statistical comparisons also present means and the corresponding standard deviation. Data analysis from part one of the experiment was performed with four repetitions ( 2 bags * 2 samples from each); part two of the experiment was performed with three repetitions, corresponding to three sausages per formulation and sampling time.

\section{Results}

\subsection{Naturally Fermented Sausage Batter}

The evolution of Salmonella, S. aureus, and L. monocytogenes in the batter is presented in Figures 2-4, respectively. The total number of combinations of effects/levels was 18 ( $2 \mathrm{NOx} * 3$ wine * 3 contamination levels) for each sampling time and each microorganism and the individual results are presented only in the figures. The results of the statistical comparisons are presented in Table 2.

Four hours after the batter's preparation, the pathogens were enumerated to check the inoculation level: Salmonella, $2.86 \pm 1.74 \log \mathrm{cfu} / \mathrm{g}$; S. aureus, $1.63 \pm 1.13$; and L. monocytogenes, $1.57 \pm 1.08 \mathrm{log} \mathrm{cfu} / \mathrm{g}$. It was observed that the recently prepared batter $(4 \mathrm{~h})$ with NOx presented slightly lower counts of Salmonella and S. aureus $(p<0.05)$ than the batter samples without NOx (Table 2, Figures 2 and 3). 

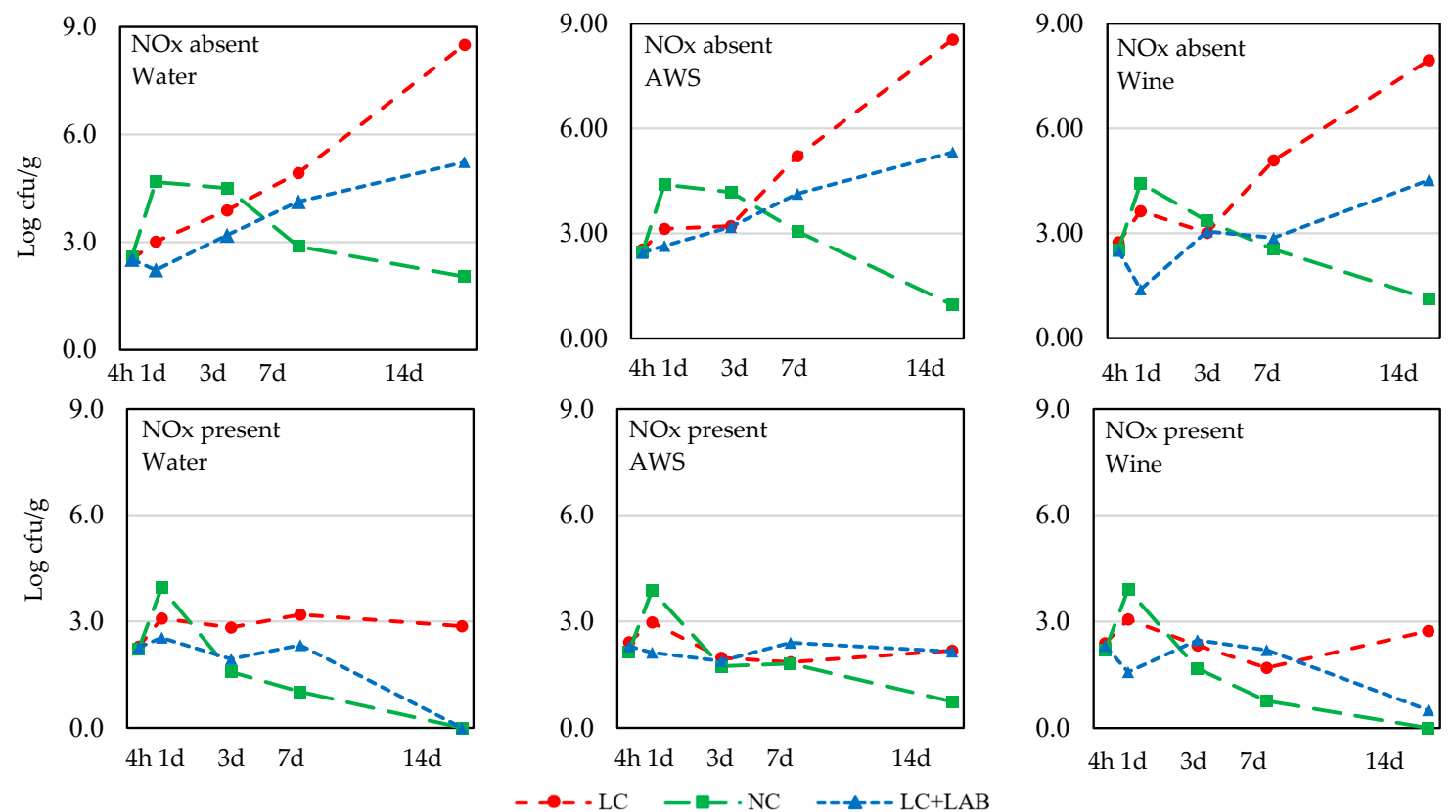

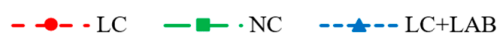

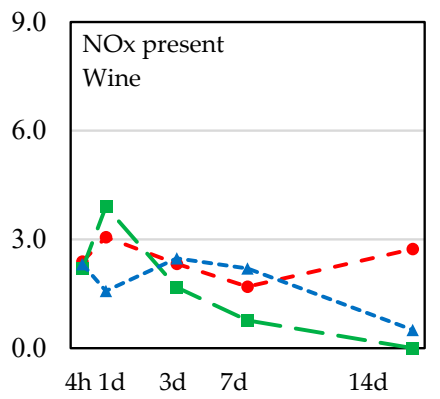

Figure 2. The behavior of Salmonella spp. during the incubation of the chouriço batter made from low contaminated meat (LC), normal contaminated meat (NC), and low contaminated meat with LAB added $(\mathbf{L C}+\mathbf{L A B})$, with or without nitrite plus nitrate (NOx) and water, artificial wine solution (AWS), or wine $(n=4)$.

The behavior of Salmonella during the experiment was influenced $(p<0.05)$ by the presence of NOx and by the contamination of the meat (Table 2). In the absence of NOx, particularly in LC meat, the multiplication of Salmonella was faster, reaching levels close to $8 \log \mathrm{cfu} / \mathrm{g}$ (Figure 2). Batter prepared with LC + LAB also had considerable growth of Salmonella spp., which was still more controlled than in the absence of LAB. When the batter was prepared with NC meat, there was an initial growth of Salmonella, but after 3 days of incubation, Salmonella loads dropped, presenting only residual counts after 14 days of incubation. No significant difference was detected for the use of wine or AWS.

S. aureus showed a behavior similar to Salmonella, but with smaller increases in the population (Figure 3). The initial contamination level of meat clearly affected the behavior of this pathogen as the higher counts were mostly observed in the batter prepared with LC meat, followed by LC + LAB. Normal contamination meat resulted in lower survival of S. aureus; after 7 or 14 days of incubation, $S$. aureus was below the detection limit. The inhibitory effect of NOx was statistically significant after $4 \mathrm{~h}$ and 3 days of drying (Table 2), with higher inhibition in samples using the additive.

L. monocytogenes presented higher growth when LC meat was used in the absence of NOx (Figure 4). The effect of the contamination level was highly significant from day 1 to the end of the experiment (Table 2). When the batter was prepared without NOx, the use of a LAB starter culture contributed to the inhibition of the pathogen. This trend was also observed when NOx was used, but in this case, batters prepared with NC meat also presented low counts of L. monocytogenes. The effect of NOx was statistically significant from 7 days of incubation and resulted in lower counts of $L$. monocytogenes. That tendency $(p=0.059)$ was observed since the third day. 

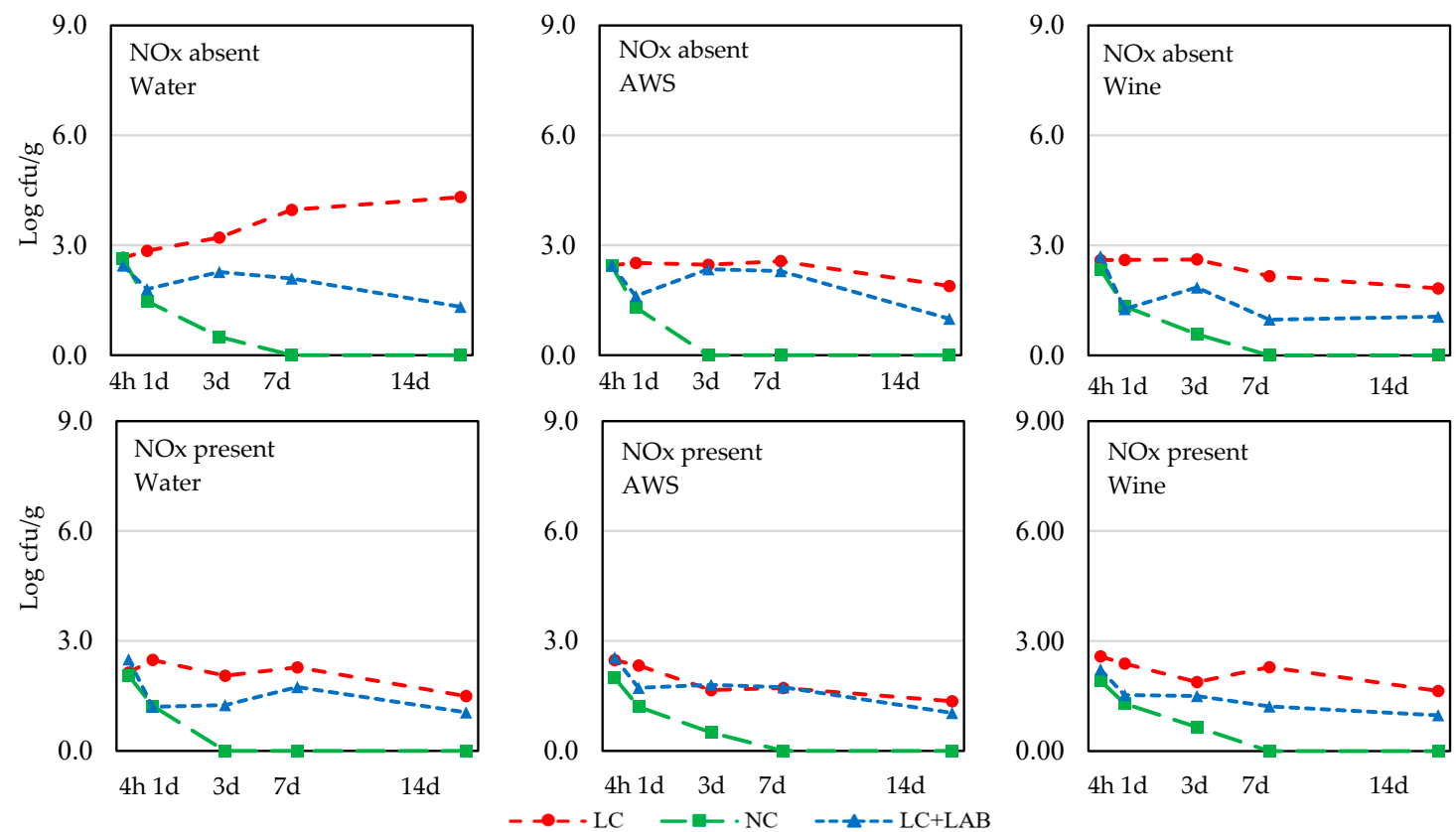

Figure 3. Behavior of $S$. aureus during incubation of chouriço batter made from low contaminated meat (LC), normal contaminated meat (NC), and low contaminated meat with LAB added (LC + LAB), with or without nitrite plus nitrate (NOx) and water, artificial wine solution (AWS), or wine $(n=4)$.
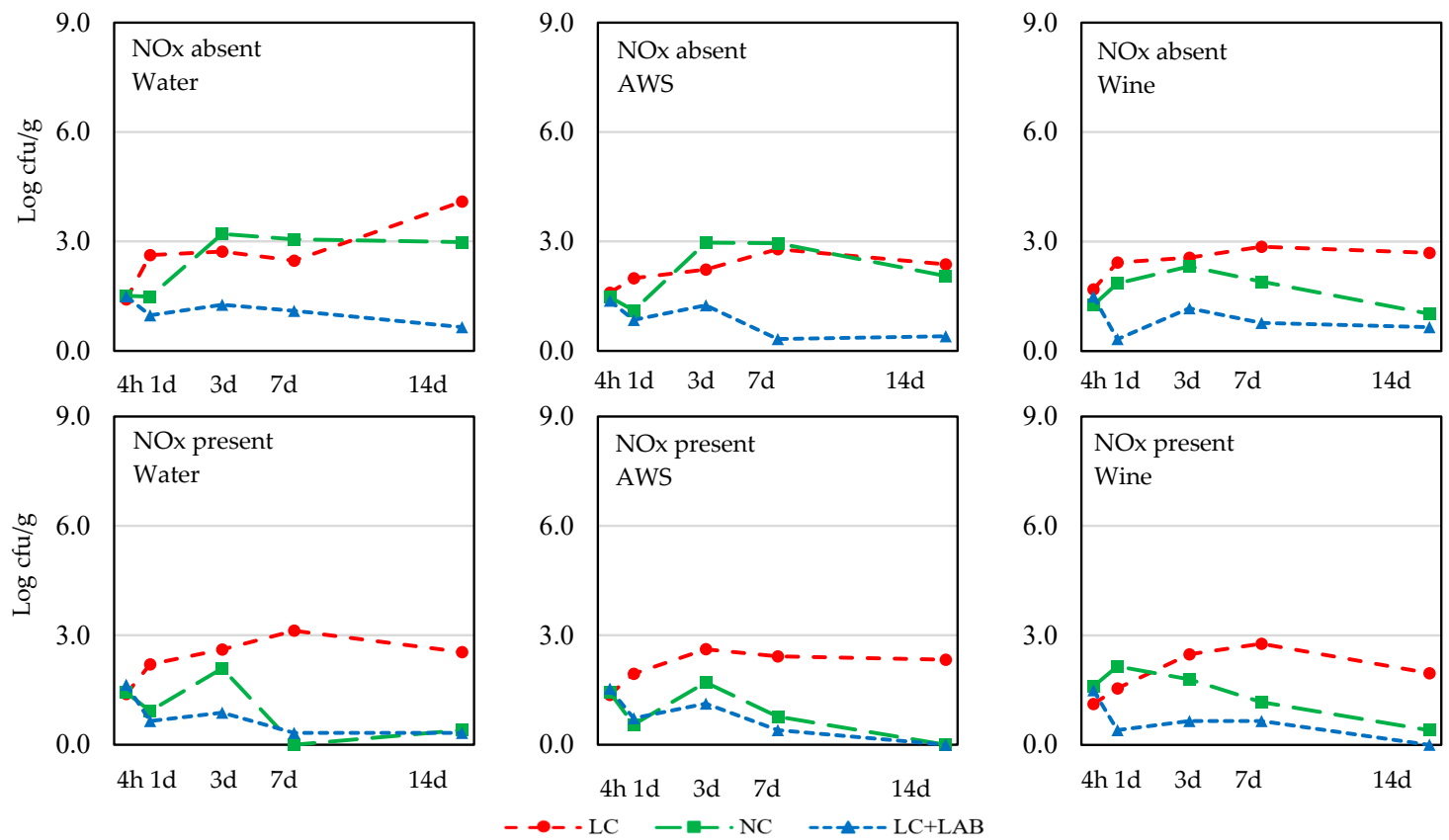

Figure 4. Behavior of L. monocytogenes during incubation of chouriço batter made from low contaminated meat (LC), normal contaminated meat (NC), and low contaminated meat with LAB added (LC + LAB), with or without nitrite plus nitrate (NOx) and water, artificial wine solution (AWS), or wine $(n=4)$. 
Table 2. Comparisons of the counts of the three pathogens in chouriço batter made with or without curing salts (NOx), with wine or artificial wine solution (AWS) or water, using low contaminated meat (LC), normal contaminated meat (NC), and low contaminated meat inoculated with L. sakei (LC + LAB). The results are expressed as the mean \pm standard deviation of $\log \mathrm{cfu} / \mathrm{g}$.

\begin{tabular}{|c|c|c|c|c|c|c|c|c|c|c|c|}
\hline \multirow{2}{*}{ Phase } & \multicolumn{3}{|c|}{ NOx } & \multicolumn{4}{|c|}{ Wine } & \multicolumn{4}{|c|}{ Contamination } \\
\hline & $\begin{array}{l}\text { Absent } \\
(n=36)\end{array}$ & $\begin{array}{l}\text { Present } \\
(n=36)\end{array}$ & $p$ & $\begin{array}{c}\text { Water } \\
(n=24)\end{array}$ & $\begin{array}{c}\text { AWS } \\
(n=24)\end{array}$ & $\begin{array}{c}\text { Wine } \\
(n=24)\end{array}$ & $p$ & $\begin{array}{c}\text { LC } \\
(n=24)\end{array}$ & $\begin{array}{c}\mathrm{NC} \\
(n=24)\end{array}$ & $\begin{array}{c}\mathrm{LC}+\mathrm{LAB} \\
(n=24)\end{array}$ & $p$ \\
\hline \multicolumn{12}{|c|}{ Salmonella } \\
\hline $1 \mathrm{~d}$ & $3.28 \pm 1.19$ & $3.01 \pm 0.96$ & ns & $3.25 \pm 0.88$ & $3.19 \pm 0.95$ & $3.00 \pm 1.38$ & ns & $3.15 \pm 0.30 b$ & $4.21 \pm 0.41 \mathrm{c}$ & $2.08 \pm 1.01 \mathrm{a}$ & $<0.001$ \\
\hline $3 \mathrm{~d}$ & $3.51 \pm 1.16$ & $2.05 \pm 1.27$ & $<0.001$ & $2.99 \pm 1.41$ & $2.70 \pm 1.41$ & $2.65 \pm 1.46$ & ns & $2.87 \pm 1.89$ & $2.84 \pm 1.97$ & $2.62 \pm 0.93$ & ns \\
\hline $7 \mathrm{~d}$ & $3.87 \pm 1.31$ & $1.92 \pm 1.32$ & $<0.001$ & $3.08 \pm 1.65$ & $3.08 \pm 1.59$ & $2.52 \pm 1.67$ & ns & $3.67 \pm 1.67 b$ & $2.01 \pm 1.80 \mathrm{a}$ & $3.01 \pm 0.89 \mathrm{ab}$ & 0.007 \\
\hline $14 \mathrm{~d}$ & $4.91 \pm 3.08$ & $1.24 \pm 1.40$ & $<0.001$ & $3.11 \pm 3.21$ & $3.31 \pm 3.01$ & $2.80 \pm 2.30$ & ns & $5.46 \pm 3.04 \mathrm{~b}$ & $0.80 \pm 1.49 \mathrm{a}$ & $2.95 \pm 2.27 \mathrm{a}$ & $<0.001$ \\
\hline $4 \mathrm{~h}$ & $2.53 \pm 0.27$ & $2.27 \pm 0.53$ & 0.010 & $2.41 \pm 0.60$ & $2.39 \pm 0.34$ & $2.39 \pm 0.34$ & ns & $2.48 \pm 0.59$ & $2.23 \pm 0.30$ & $2.48 \pm 0.32$ & ns \\
\hline $1 \mathrm{~d}$ & $1.86 \pm 0.86$ & $1.71 \pm 0.75$ & $\mathrm{~ns}$ & $1.84 \pm 0.90$ & $1.78 \pm 0.71$ & $1.73 \pm 0.82$ & ns & $2.58 \pm 0.29 b$ & $1.30 \pm 0.83 \mathrm{a}$ & $1.52 \pm 0.58 \mathrm{a}$ & $<0.001$ \\
\hline $3 \mathrm{~d}$ & $1.76 \pm 1.21$ & $1.25 \pm 0.95$ & 0.017 & $1.55 \pm 1.24$ & $1.46 \pm 1.05$ & $1.51 \pm 1.07$ & ns & $2.31 \pm 0.64 b$ & $0.37 \pm 0.85 a$ & $1.84 \pm 0.72 b$ & $<0.001$ \\
\hline $7 \mathrm{~d}$ & $1.56 \pm 1.39$ & $1.22 \pm 1.05$ & ns & $1.68 \pm 1.43$ & $1.38 \pm 1.19$ & $1.11 \pm 1.03$ & ns & $2.49 \pm 0.95 c$ & $<\mathrm{DLa}$ & $1.67 \pm 0.66 \mathrm{~b}$ & $<0.001$ \\
\hline $14 \mathrm{~d}$ & $1.27 \pm 1.65$ & $0.84 \pm 0.90$ & ns & $1.36 \pm 1.54$ & $0.88 \pm 1.27$ & $0.92 \pm 1.18$ & ns & $2.09 \pm 1.60 \mathrm{~b}$ & $<\mathrm{DLa}$ & $1.07 \pm 0.82 \mathrm{a}$ & $<0.001$ \\
\hline \multicolumn{12}{|c|}{ L. monocytogenes } \\
\hline $4 \mathrm{~h}$ & $1.48 \pm 0.39$ & $1.44 \pm 0.56$ & ns & $1.48 \pm 0.56$ & $1.47 \pm 0.40$ & $1.44 \pm 0.37$ & ns & $1.43 \pm 0.68$ & $1.45 \pm 0.29$ & $1.51 \pm 0.22$ & ns \\
\hline $1 \mathrm{~d}$ & $1.51 \pm 0.99$ & $1.23 \pm 0.99$ & ns & $1.48 \pm 0.99$ & $1.19 \pm 1.00$ & $1.45 \pm 1.01$ & ns & $2.12 \pm 0.59 c$ & $1.34 \pm 1.02 b$ & $0.65 \pm 0.74 \mathrm{a}$ & $<0.001$ \\
\hline $14 \mathrm{~d}$ & $1.88 \pm 1.40$ & $0.88 \pm 1.67$ & 0.003 & $1.83 \pm 1.57$ & $1.19 \pm 1.25$ & $1.12 \pm 1.21$ & ns & $2.66 \pm 0.87 b$ & $1.14 \pm 1.34 \mathrm{a}$ & $0.34 \pm 0.60 \mathrm{a}$ & $<0.001$ \\
\hline
\end{tabular}

$\mathrm{a}, \mathrm{b}, \mathrm{c}$, Means in the same line under the same heading are different $(p<0.05)$. ns, not significant. 
The approach used in this part of the experiment has the limitation of challenging the pathogens in the batter without the effect of drying. However, these results allow us to understand each factor's effect, simulating the first stages of naturally fermented sausage processing. The baseline of natural contamination of meat was around $3.27 \pm 0.34 \mathrm{log} \mathrm{cfu} / \mathrm{g}$ Enterobacteriaceae, $3.24 \pm 0.33 \mathrm{log} \mathrm{cfu} / \mathrm{g}$ Pseudomonas, and $4.75 \pm 0.27 \log \mathrm{cfu} / \mathrm{g} \mathrm{LAB}$ in NC meat. The procedure used to reduce to contamination resulted in a reduction of nearly $1.2 \mathrm{log} \mathrm{cfu} / \mathrm{g}$ for the gram-negative bacteria and $1.8 \mathrm{log} \mathrm{cfu} / \mathrm{g}$ for the LAB. These reductions were all significant $(p<0.05)$. The overgrowth of gram-negative spoilage microorganisms (Figure 5) should be taken into consideration when analyzing these results as these organisms are highly uncommon in fermented meat products since they die when the product dries [29]. The LAB population, both in the LC + LAB or LC and NC samples, is characteristic of these products (Figure 6). At the beginning of the experiment, the difference between LC + LAB $(8.23 \pm 0.38 \mathrm{log} \mathrm{cfu} / \mathrm{g})$ and LC $(2.92 \pm 0.32 \log \mathrm{cfu} / \mathrm{g})$ was around $5.3 \log \mathrm{cfu} / \mathrm{g}$, which is slightly lower than the previewed inoculation of $6 \mathrm{log} \mathrm{cfu} / \mathrm{g}$. The difference between the previewed and observed inoculation level indicates that the L. sakei population suffered some lethality when introduced in the meat batters, which is common when preparing fermented sausage batters [30]. The initial count of LAB in NC was $4.75 \pm 0.27 \log \mathrm{cfu} / \mathrm{g}$. As the experiment proceeded, the differences between $\mathrm{LC}, \mathrm{NC}$, and LC $+\mathrm{BAL}$ became narrower, to nearly $2 \log \mathrm{cfu} / \mathrm{g}$ at 14 days.
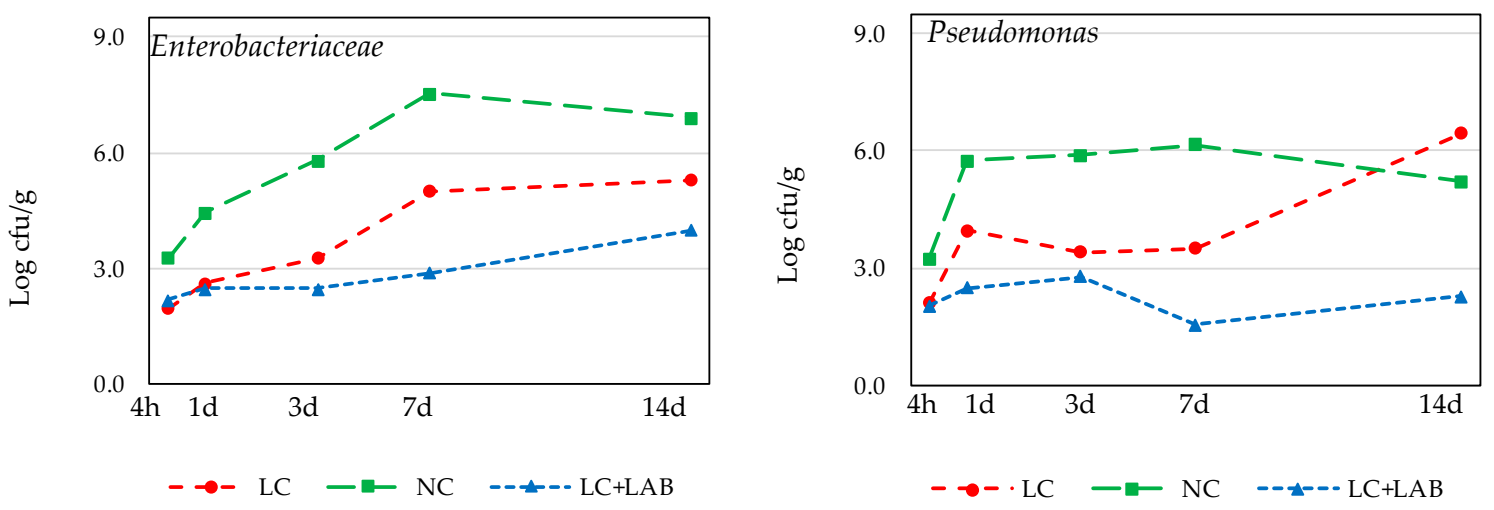

Figure 5. Counts of Enterobacteriaceae and Pseudomonas during incubation of chouriço batter made from low contaminated meat (LC), normal contaminated meat (NC), and low contaminated meat with LAB.

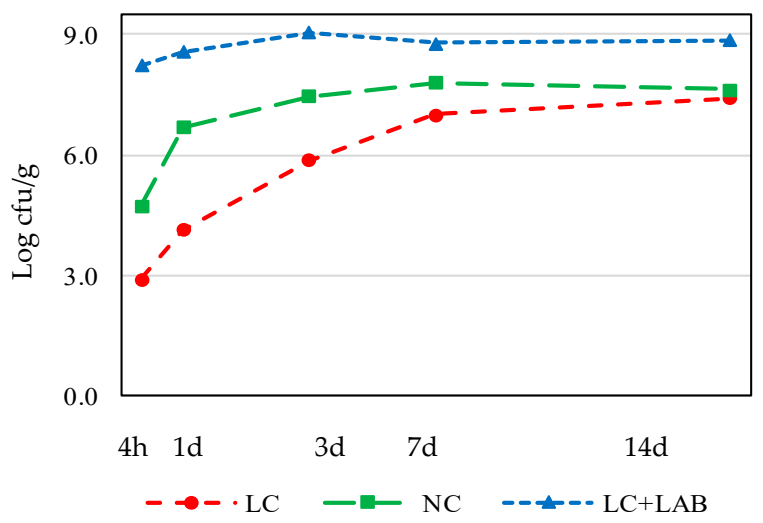

Figure 6. Counts of LAB during incubation of chouriço batter made from low contaminated meat (LC), normal contaminated meat (NC), and low contaminated meat with LAB added (LC + LAB). Combined results of samples with or without nitrite plus nitrate and water, artificial wine solution (AWS), or wine $(n=24)$.

It is not our intention to advocate the use of highly contaminated meat in the manufacture of naturally fermented sausages. However, one should consider not only meat with low initial microbiota due to high hygiene standards in the abattoir and carcass dressing, but also the current trend to 
decontaminate meat. The use of lactic and acetic acid has been considered in EU to decontaminate pig carcasses [31]. Other strategies have been proposed to decontaminate carcasses and meat based on chemical or physical treatments [32-34]. Considering that meat is a sensitive microbial ecosystem, these practices might result in overgrowth of pathogens that are more resistant to the treatment and the eventual emergence of pathogens that are usually of low concern [31]. The present study's results confirm that the higher the competition in the batter, the more difficult it is for a pathogen to grow or survive, particularly if no other hurdles are introduced in the process [7,35]. This situation is of particular concern with Salmonella, which is an excellent competitor [36]. S. aureus' ability to compete has been described as limited [37], which is represented in the present results, as S. aureus was largely influenced by the initial contamination of meat. L. monocytogenes has been suggested to be a good competitor, particularly at refrigeration temperatures [38]. The present experiment was performed at $15^{\circ} \mathrm{C}$, which favors the growth of other bacteria, namely LAB. The counts of L. monocytogenes were maintained, in the worst scenario, at levels similar to the initial contamination, with the exception of the batter prepared without NOx and with no wine or AWS. The use of L. sakei as a starter culture has been confirmed to be an interesting strategy to control the multiplication of pathogens, particularly when low contaminated meat is used. Several authors have demonstrated that L. monocytogenes is inhibited more rapidly when LAB starter cultures are added to the manufacturing of dry-fermented sausage, among other factors, due to bacteriocins' production, which are active against this pathogen [30]. The adaptation of LAB naturally present in the raw materials and the excellent adaptation of LAB to the sausage ecosystem results in the growth and dominance of the sausage microbiota in a few days [39]. Besides the environmental competitive advantage of $\mathrm{LAB}$, the ability to eliminate competitors through bacteriocins also contributes to the interest of using LAB in starter cultures. The LAB bacteriocins are particularly active against gram-positive bacteria, which might justify the behavior of S. aureus and L. monocytogenes in the present work when L. sakei was used. The effect on gram-negative bacteria is variable since the outer lipopolysaccharide layer of gram-negative bacteria exerts a protective effect against the action of bacteriocins [30]. Considering the current trend in the meat industry to reduce the use of NOx [40], the results of the present experiment are worrying as the presence of NOx results in a better inhibition of the challenging pathogens. NOx is used mainly to control Cl. botulinum [10]. In accordance with our results, the inhibition of Salmonella, S. aureus, and L. monocytogenes was also demonstrated [21,41-43]. The broad antimicrobial effect of nitrite is due to the action of nitric oxide on Fe-S enzyme complexes, which are vital for cellular functions in several bacteria [11]. Several strategies have been proposed to replace nitrite based on vegetable extracts with high content in nitrate, based on controlled fermentation with protective microorganisms, or other innovative preservation methods [40]. The efficacy of hurdle technology has also been revisited to justify the control of Clostridium and other pathogens in nitrite-free, dry-cured, or dry fermented sausages [10,12,43,44].

The results observed in this part of the study cannot be compared to the pathogens' behavior in the industry since the drying and smoking hurdles were missing. Particularly, drying has a high impact on pathogen control. The effect of the wine, or AWS, was rare or indirect. The results of the present study showed that the inhibition obtained with wine is similar to that obtained with AWS, suggesting that organic acids and ethanol are the main compounds that contribute to the inhibitory effect of wine since the AWS did not have phenolic compounds, which are reputed for their antimicrobial activity.

\subsection{Part 2. Naturally Fermented Sausage—Chouriço}

The chouriço prepared with different formulations presented a level of pathogen inoculation ( $4 \mathrm{~h}$ ) between 2 and $2.5 \mathrm{log}$ cfu/g (Table 3). At the end of smoking (1 day), the abundance of the three pathogens in the control samples increased slightly, while when wine was used, the abundance decreased by approximately $1 \log \mathrm{cfu} / \mathrm{g}$. The combined effect of wine and LAB resulted in counts below the detection limit for the three repetitions immediately after smoking. On the seventh day of drying, $\mathrm{a}_{\mathrm{w}}$ was already below 0.95 (Figure 7), resulting in lower counts of Salmonella and S. aureus, similar $(p>0.05)$ to those found in the three types of chouriço tested. Lactic acid bacteria counts, 
$4 \mathrm{~h}$ after preparation, were different between non-inoculated and inoculated samples by approximately $4 \log \mathrm{cfu} / \mathrm{g}$. These differences became narrower to approximately $0.5 \log \mathrm{cfu} / \mathrm{g}$ after 7 days of drying and almost disappeared at 14 days of drying. The normal spoilage microbiota of the meat was initially present in low counts and progressively disappeared. At 7 days of drying, Enterobacteriaceae and Pseudomonas were below the detection limit.

The evolution of $\mathrm{pH}$ (Figure 7) is characteristic of fermented sausage [30]. The reduction in $\mathrm{pH}$ was more evident in sausages made with wine with a low $\mathrm{pH}$, and vestigial amounts of sugars also contributed to lactic fermentation [12]. Chouriço technology is based on natural fermentation. It is not common to add fermentable sugar to the batter, which is why the $\mathrm{pH}$ is never very low. The final product had a $\mathrm{pH}$ slightly higher than 5 , which was not sufficiently reduced to be considered a stability parameter.

The results demonstrate the importance of correctly drying fermented sausages, which is the main factor responsible for its safety. The effect of wine, as well as the combination of wine with LAB, on reducing the time necessary to eliminate the pathogens of concern must be stressed as it allows the producer to eventually deem the product finished, even with a slightly higher $\mathrm{a}_{\mathrm{w}}$ than usual, improving juiciness and yield.

Table 3. Counts of the three pathogens in the present study and LAB in chouriço made without wine (control), supplemented with $7.5 \%$ red wine (wine) and with the additional inoculation of $6 \log \mathrm{cfu} / \mathrm{g}$ L. sakei (Wine $+\mathrm{LAB})$. The results are expressed as the mean \pm standard deviation of $\log \mathrm{cfu} / \mathrm{g}$.

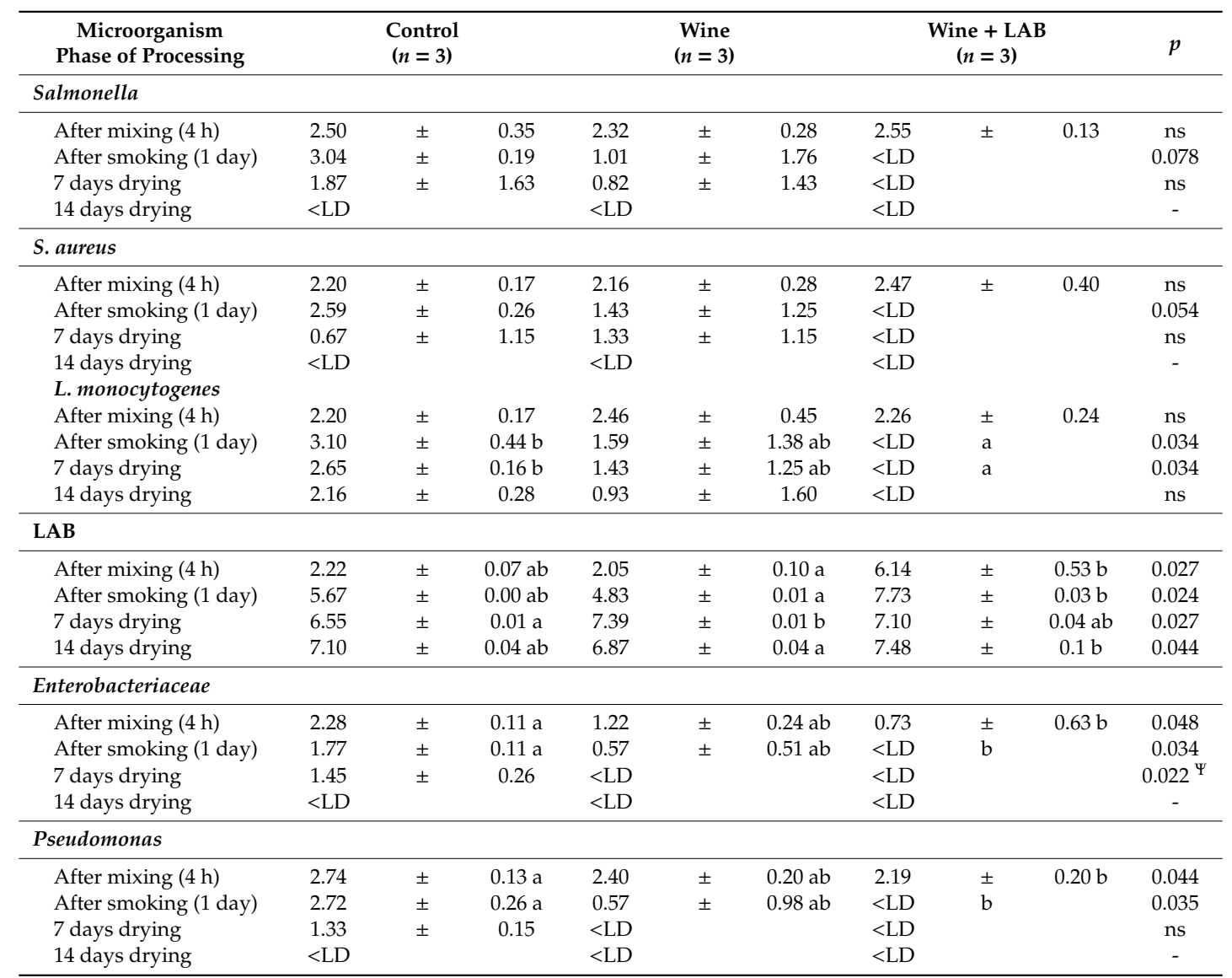

$\mathrm{a}, \mathrm{b}, \mathrm{c}$, means in the same line with different letters are different $(p<0.05) ; \mathrm{ns}$, not significant; ${ }^{\Psi}$ although the $p$-value is significant, the individual differences were not significant. 

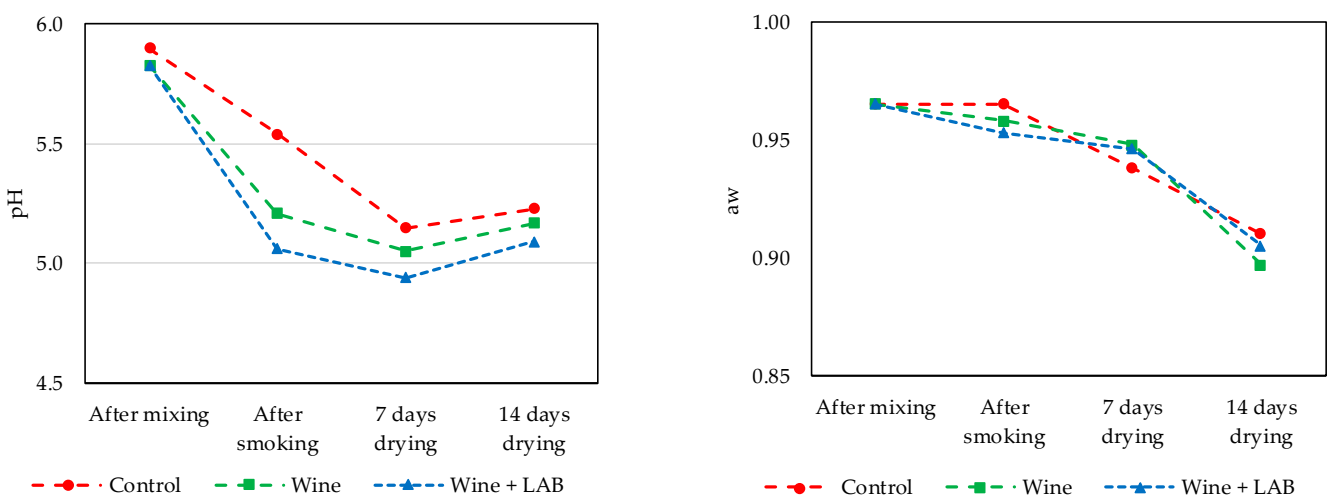

Figure 7. $\mathrm{pH}$ values (left) and water activity (right) measured in chouriço during processing $(n=3)$.

\section{Conclusions}

The results of the present study performed with naturally fermented sausage batter revealed that the reduced contamination in raw meat might be a favorable factor for the multiplication of pathogens. The inhibitory effect of NOx on Salmonella, S. aureus, and L. monocytogenes was confirmed. This additive showed increased importance for achieving inhibition as the competition in meat was lower. Thus, any attempt to reduce or eliminate NOx from dry-cured sausages should consider the use of LAB starter cultures to ensure an unfavorable competition environment for the pathogens that will eventually be present. When the naturally fermented sausages were dried, $\mathrm{a}_{\mathrm{w}}$ reduction resulted in a strong inhibition of the tested pathogens. That inhibition was more effective when red wine was used or when used in combination with the LAB starter culture.

Author Contributions: Conceptualization, L.P., Investigation L.P. and M.N., Formal analysis L.P. and J.A.S., Writing-Original Draft L.P. and M.J.F.; Writing-Review \& Editing, J.A.S., Funding acquisition M.J.F. and L.P. All authors have read and agreed to the published version of the manuscript.

Funding: This research was funded by GO77 PDR2020-1.0.1-FEADER-0313; Project UIDB/CVT/00772/2020 and Project UIDP/CVT/00276/2020 and supported by the Foundation for Science and Technology (FCT). M.J.F. is a member of network Red CYTED HEALTHY MEAT (119RT0568).

Acknowledgments: The authors would like to thank Ana Leite for her technical assistance.

Conflicts of Interest: The authors declare no conflict of interest.

\section{References}

1. EFSA; ECDC. The European Union One Health 2018 Zoonoses Report. EFSA J. 2019, 17. [CrossRef]

2. CDC. CDC 2015 Surveillance Report—FoodNet. 2017. Available online: https://www.cdc.gov/foodnet/pdfs/ FoodNet-Annual-Report-2015-508c.pdf (accessed on 22 May 2020).

3. Holck, A.; Axelsson, L.; McLeod, A.; Rode, T.M.; Heir, E. Health and safety considerations of fermented sausages. J. Food Qual. 2017, 2017, 1-25. [CrossRef]

4. Meloni, D. Presence of Listeria monocytogenes in mediterranean-style dry fermented sausages. Foods 2015, 4, 34-50. [CrossRef] [PubMed]

5. Kadariya, J.; Smith, T.C.; Thapaliya, D. Staphylococcus aureus and staphylococcal food-borne disease: An ongoing challenge in public health. BioMed Res. Int. 2014, 2014, 827965. [CrossRef]

6. Freilich, S.; Zarecki, R.; Eilam, O.; Segal, E.S.; Henry, C.S.; Kupiec, M.; Gophna, U.; Sharan, R.; Ruppin, E. Competitive and cooperative metabolic interactions in bacterial communities. Nat. Commun. 2011, 2, 589. [CrossRef]

7. Simon-Cornu, M.; Billoir, E.; Bergis, H.; Beaufort, A.; Zuliani, V. Modeling microbial competition in food: Application to the behavior of Listeria monocytogenes and lactic acid flora in pork meat products. Food Microbiol. 2011, 28, 639-647. [CrossRef]

8. Laranjo, M.; Elias, M.; Fraqueza, M. The use of starter cultures in traditional meat products. J. Food Qual. 2017, 2017, 1-18. [CrossRef] 
9. Talon, R.; Leroy, S. Diversity and safety hazards of bacteria involved in meat fermentations. Meat Sci. 2011, 89, 303-309. [CrossRef]

10. Hospital, X.F.; Hierro, E.; Stringer, S.; Fernández, M. A study on the toxigenesis by Clostridium botulinum in nitrate and nitrite-reduced dry fermented sausages. Int. J. Food Microbiol. 2016, 218, 66-70. [CrossRef]

11. Majou, D.; Christieans, S. Mechanisms of the bactericidal effects of nitrate and nitrite in cured meats. Meat Sci. 2018, 145, 273-284. [CrossRef]

12. Patarata, L.; Martins, S.; Silva, J.A.; Fraqueza, M. Red wine and garlic as a possible alternative to minimize the use of nitrite for controlling clostridium sporogenes and salmonella in a cured sausage: Safety and sensory implications. Foods 2020, 9, 206. [CrossRef] [PubMed]

13. IARC. Red Meat and Processed Meat; IARC Working Group on the Evaluation of Carcinogenic Risks to Humans International Agency for Research on Cancer: Geneva, Switzerland, 2018; Volume 114.

14. Di Vita, G.; Blanc, S.; Mancuso, T.; Massaglia, S.; La Via, G.; D'Amico, M. Harmful Compounds and Willingness to Buy for Reduced-Additives Salami. Outlook Ital. Consum. Int. J. Environ. Res. Public Health 2019, 16, 2605. [CrossRef] [PubMed]

15. Martins, N.; Ferreira, I.C.; Martins, N. Mountain food products: A broad spectrum of market potential to be exploited. Trends Food Sci. Technol. 2017, 67, 12-18. [CrossRef]

16. Mortensen, A.; Aguilar, F.; Crebelli, R.; Di Domenico, A.; Dusemund, B.; Frutos, M.J.; Galtier, P.; Gott, D.; Gundert-Remy, U.; Lambre, C.; et al. Re-evaluation of potassium nitrite (E 249) and sodium nitrite (E 250) as food additives. EFSA J. 2017, 15. [CrossRef]

17. Fraqueza, M.J.; Patarata, L. Fermented Meat Products: From the Technology to the Quality Control. In Fermented Food Products; Sankaranarayanan, A., Amaresan, N., Dhanasekaran, D., Eds.; CRC Press: Boca Raton, FL, USA, 2020; pp. 197-237.

18. García-Díez, J.; Alheiro, J.; Pinto, A.L.; Soares, L.; Falco, V.; Fraqueza, M.J.; Patarata, L. The Impact of Essential Oils on Consumer Acceptance of Chouriço de vinho-A Dry-Cured Sausage Made from Wine-Marinated Meat-Assessed by the Hedonic Scale, JAR Intensity Scale and Consumers' "Will to Consume and Purchase". J. Food Process. Preserv. 2017, 41. [CrossRef]

19. Coloretti, F.; Tabanelli, G.; Chiavari, C.; Lanciotti, R.; Grazia, L.; Gardini, F.; Montanari, C. Effect of wine addition on microbiological characteristics, volatile molecule profiles and biogenic amine contents in fermented sausages. Meat Sci. 2014, 96, 1395-1402. [CrossRef]

20. Rason, J.; Laguet, A.; Berge, P.; Dufour, E.; Lebecque, A. Investigation of the physicochemical and sensory homogeneity of traditional French dry sausages. Meat Sci. 2007, 75, 359-370. [CrossRef]

21. Cadavez, V.; Gonzales-Barron, U.; Pires, P.; Fernandes, E.; Pereira, A.P.; Gomes, A.; Araújo, J.P.; Lopes-Da-Silva, F.; Morales, P.; Fernandes, C.; et al. An assessment of the processing and physicochemical factors contributing to the microbial contamination of salpicão, a naturally-fermented Portuguese sausage. LWT Food Sci. Technol. 2016, 72, 107-116. [CrossRef]

22. Spaziani, M.; Del Torre, M.; Stecchini, M.L. Changes of physicochemical, microbiological, and textural properties during ripening of Italian low-acid sausages. Proteolysis, sensory and volatile profiles. Meat Sci. 2009, 81, 77-85. [CrossRef]

23. Díez, J.G.; Patarata, L. Behavior of Salmonella spp., Listeria monocytogenes, and Staphylococcus aureus in chouriço de vinho, a dry fermented sausage made from wine-marinated meat. J. Food Prot. 2013, 76, 588-594.

24. Silva, V.; Igrejas, G.; Falco, V.; Santos, T.P.; Torres, C.; Oliveira, A.M.; Pereira, J.E.; Amaral, J.S.; Poeta, P. Chemical composition, antioxidant and antimicrobial activity of phenolic compounds extracted from wine industry by-products. Food Control. 2018, 92, 516-522. [CrossRef]

25. Augustin, J.-C.; Bergis, H.; Midelet-Bourdin, G.; Simon-Cornu, M.; Couvert, O.; Denis, C.; Huchet, V.; Lemonnier, S.; Pinon, A.; Vialette, M.; et al. Design of challenge testing experiments to assess the variability of Listeria monocytogenes growth in foods. Food Microbiol. 2011, 28, 746-754. [CrossRef]

26. Pereira, J.; Silva, P.; Matos, T.; Patarata, L. Shelf Life Determination of Sliced Portuguese Traditional Blood Sausage- Morcela de Arroz de Monchique through Microbiological Challenge and Consumer Test. J. Food Sci. 2015, 80, M642-M648. [CrossRef]

27. Linares, M.; Garrido, M.D.; Martins, C.; Patarata, L. Efficacies of Garlic and L. sakei in Wine-Based Marinades for Controlling Listeria monocytogenes and Salmonella spp. in Chouriço de Vinho, a Dry Sausage Made from Wine-Marinated Pork. J. Food Sci. 2013, 78. [CrossRef] [PubMed] 
28. Cristino, R.; Costa, E.; Cosme, F.; Jordão, A.M. General phenolic characterisation, individual anthocyanin and antioxidant capacity of matured red wines from two Portuguese Appellations of Origins. J. Sci. Food Agric. 2013, 93, 2486-2493. [CrossRef] [PubMed]

29. Alfaiaa, A.; Alfaiab, C.M.; Patarata, L.; Fernandes, M.J.; Fernandes, M.H.; Eliasd, M.; Ribeiro, M.H.; Fraqueza, M.J. Binomial effects of high isostatic pressure and time on the microbiological, sensory characteristics and lipid composition stability of vacuum packed dry fermented sausages 'chouriço'. Innov. Food Sci. Emerg. Technol. 2015, 32,37-44. [CrossRef]

30. Fraqueza, M.J.; Patarata, L.; Lauková, A. Protective cultures and bacteriocins. In Fermented Meat Products. Health Aspects; Zdolec, N., Ed.; CRC Press Taylor \& Francis Group: Boca Raton, FL, USA, 2017; pp. 228-269. [CrossRef]

31. Silano, V.; Baviera, J.M.B.; Bolognesi, C.; Brüschweiler, B.J.; Chesson, A.; Cocconcelli, P.S.; Crebelli, R.; Gott, D.M.; Grob, K.; Lampi, E.; et al. Evaluation of the safety and efficacy of the organic acids lactic and acetic acids to reduce microbiological surface contamination on pork carcasses and pork cuts. EFSA J. 2018, 16. [CrossRef]

32. Dickson, J.S.; Anderson, M.E. Microbiological decontamination of food animal carcasses by washing and sanitizing systems: A Review. J. Food Prot. 1992, 55, 133-140. [CrossRef]

33. Duan, D.; Wang, H.; Xue, S.; Li, M.; Xu, X. Application of disinfectant sprays after chilling to reduce the initial microbial load and extend the shelf-life of chilled chicken carcasses. Food Control. 2017, 75, 70-77. [CrossRef]

34. Reichel, J.; Kehrenberg, C.; Krischek, C. Inactivation of Yersinia enterocolitica and Brochothrix thermosphacta on pork by UV-C irradiation. Meat Sci. 2019, 158, 107909. [CrossRef]

35. EFSA. Growth of spoilage bacteria during storage and transport of meat. EFSA J. 2016, 14, 4523. [CrossRef]

36. Møller, C.; Ilg, Y.; Aabo, S.; Christensen, B.; Dalgaard, P.; Hansen, T.B. Effect of natural microbiota on growth of Salmonella spp. in fresh pork-A predictive microbiology approach. Food Microbiol. 2013, 34, $284-295$.

37. Gonzales-Barron, U.; Cadavez, V.; Pereira, A.P.; Gomes, A.; Araújo, J.P.; Saavedra, M.; Estevinho, L.; Butler, F.; Pires, P.; Dias, T. Relating physicochemical and microbiological safety indicators during processing of linguiça, a Portuguese traditional dry-fermented sausage. Food Res. Int. 2015, 78, 50-61. [CrossRef] [PubMed]

38. Thakur, M.; Asrani, R.K.; Patial, V. Listeria monocytogenes: A Food-Borne Pathogen. Foodborne Dis. 2018, 55, 157-192.

39. Baka, A.; Papavergou, E.; Pragalaki, T.; Bloukas, J.G.; Kotzekidou, P. Effect of selected autochthonous starter cultures on processing and quality characteristics of Greek fermented sausages. LWT Food Sci. Technol. 2011, 44, 54-61. [CrossRef]

40. Fraqueza, M.J.; Borges, A.F.; Patarata, L. Strategies to reduce the formation of carcinogenic chemicals in dry cured meat products. Food Control Biosecur. 2018, 16, 295-342.

41. Mataragas, M.; Alessandria, V.; Rantsiou, K.; Cocolin, L. Evaluation of the Listeria monocytogenes inactivation during post-process storage of fermented sausages: A basis for the development of a decision support tool. Food Control. 2015, 50, 568-573. [CrossRef]

42. Christieans, S.; Picgirard, L.; Parafita, E.; Lebert, A.; Gregori, T. Impact of reducing nitrate/nitrite levels on the behavior of Salmonella Typhimurium and Listeria monocytogenes in French dry fermented sausages. Meat Sci. 2018, 137, 160-167. [CrossRef]

43. Hospital, X.F.; Hierro, E.; Fernández, M. Effect of reducing nitrate and nitrite added to dry fermented sausages on the survival of Salmonella Typhimurium. Food Res. Int. 2014, 62, 410-415. [CrossRef]

44. Hospital, X.F.; Hierro, E.; Fernández, M. Survival of Listeria innocua in dry fermented sausages and changes in the typical microbiota and volatile profile as affected by the concentration of nitrate and nitrite. Int. J. Food Microbiol. 2012, 153, 395-401. [CrossRef]

(C) 2020 by the authors. Licensee MDPI, Basel, Switzerland. This article is an open access article distributed under the terms and conditions of the Creative Commons Attribution (CC BY) license (http://creativecommons.org/licenses/by/4.0/). 